\title{
SPECIFIČNOSTI I DEVIJACIJE U UPRAVLJANJU U SUSTAVU LOKALNE SAMOUPRAVE - GRAD KASTAV: STUDIJA SLUČAJA
}

Primljen: 16. srpnja 2019.

Prihvaćen: 16. rujna 2019.

Stručni rad

\section{Sažetak}

U radu se razmatra sustav upravljanja i devijacija koje se pojavljuju u upravljanju u sustavu lokalne samouprave. Ciljevi ovog istraživanja jesu istražiti funkcije upravljanja u lokalnoj samoupravi, performanse javnih menadžera i nepravilnosti u primjeni zakonskog okvira kojim se uređuje sustav upravljanja. $U$ empirijskom su istraživanju analizirane ostvarene performanse javnih menadžera najviše razine u sustavu lokalne samouprave te je izvršena usporedba dobivenih rezultata radi utvrđivanja zajedničkih značajki performansi i razlika među njima. Rezultati istraživanja ukazuju na moguće probleme agenata koji se pojavljuju kad određene interesne skupine vode poslove za druge interesne skupine i ako jedna interesna skupina forsira svoje interese na račun druge interesne skupine. $U$ ovom se radu ukazuje na nepravilnosti koje se pojavljuju prilikom tumačenja $i$ primjene postojećeg zakonskog teksta te se ukazuje na potrebu izmjene postojeće pravne regulative kako bismo omogućili bolju primjenu prava i unaprijedili sustav upravljanja u lokalnoj samoupravi.

Ključne riječi: upravljanje, sustav lokalne samouprave, javni menadžeri, pravna regulativa, problemi agenata

JEL: H0 


\section{UVOD}

Upravljanje jedinicama lokalne, područne i regionalne samouprave postaje jednako važno kao i upravljanje drugim poslovnim i socijalnim sustavima. Menadžeri alociraju ljudske i materijalne resurse, usmjeravaju operacije u poslovnom i socijalnom sustavu te planiraju i pokušavaju odrediti najefikasniji put ostvarenja ciljeva. Ostvarivanje ciljeva poslovnog sustava zahtijeva kolektivnu akciju koja je nezamisliva bez menadžmenta koji je odgovoran za ostvarenje ciljeva i koji osigurava potporu obavljajući svoje specifične funkcije. Time se stvaraju uvjeti za efektivnu i efikasnu uporabu drugih u ostvarivanju ciljeva poslovnog i socijalnog sustava (Buble, 2006).

U jedinicama lokalne, područne i regionalne samouprave (JLPRS) se mogu identificirati sljedeći tipovi javnog menadžmenta: menadžeri na najvišoj razini odnosno gradonačelnici/općinski načelnici/župani i njihovi zamjenici, menadžeri na srednjoj razini ili pročelnici upravnih odjela i menadžeri na prvoj razini odnosno voditelji odsjeka. Zakon o sustavu unutarnjih kontrola u javnom sektoru ${ }^{1}$ uređuje sustav unutarnjih kontrola u javnom sektoru te odgovornosti i nadležnosti u razvoju sustava unutarnjih kontrola čija je svrha unapređenje upravljanja radi postizanja općih ciljeva. Financijsko upravljanje u jedinicama lokalne samouprave u kontekstu Zakona o sustavu unutarnjih kontrola u javnom sektoru predstavlja usmjeravanje i kontroliranje financijskih učinaka poslovanja radi ostvarenja poslovnih ciljeva, uz upotrebu sredstava na pravilan, etičan, djelotvoran i ekonomičan način. Resursi koji se koriste su ograničeni pa javni menadžeri moraju osigurati efektivno i efikasno korištenje ograničenih resursa.

Iako se biraju političkim putem, gradonačelnici, načelnici, župani i njihovi zamjenici predstavljaju javne menadžere najviše razine koji moraju imati potrebne konceptualne i tehničke vještine kako bi efikasno obavljali funkcije upravljanja. Zakon o lokalnim izborima ne propisuje opće uvjete koje bi morali zadovoljiti kandidati za gradonačelnike, načelnike, župane i njihove zamjenike. Prema tome, za javne menadžere najviše razine mogu biti izabrane osobe koje nisu razvile potrebne konceptualne i tehničke vještine. U skladu s tim postavljena je sljedeća hipoteza istraživanja: hrvatski zakonodavac bi morao izmijeniti postojeću pravnu regulativu kojom se uređuje izbor općinskih načelnika, gradonačelnika i njihovih zamjenika te sustav upravljanja u JLPRS s ciljem unapređenja sustava upravljanja i bolje primjene prava u JLPRS.

U ovom se istraživanju ukazuje na nepravilnosti u primjeni zakonskog okvira kojim se uređuje sustav upravljanja u lokalnoj samoupravi te se daju prijedlozi za izmjenu postojeće pravne regulative kako bi osigurali bolju primjenu prava.

Zakon o sustavu unutarnjih kontrola u javnom sektoru, Narodne novine, br. 78/15 
U okviru analize slučaja istražene su funkcije upravljanja u gradu Kastvu, izvršena je analiza performansi javnih menadžera najviše razine i analiza zakonskog okvira kojim se uređuje sustav upravljanja u sustavu lokalne samouprave. Ciljevi su ovog rada dati doprinos debati o devijacijama u upravljanju u sustavu lokalne samouprave istraživanjem problema agenata i nepravilnosti u primjeni pravne regulative. $\mathrm{U}$ ovome se radu analiziraju instrumenti za postavljanje dobre strategije upravljanja u sustavu lokalne samouprave te daju prijedlozi za izmjenu postojeće pravne regulative $\mathrm{u}$ funkciji unapređenja upravljanja i prevladavanja problema agenata.

\section{TEORIJSKE ZNAČAJKE UPRAVLJANJA U LOKALNOJ SAMOUPRAVI}

\subsection{Funkcije upravljanja i njihova povezanost s pravnom regulativom}

Primarni zadatci javnih menadžera proizlaze iz procesa upravljanja, odnosno oni planiraju i donose odluke, organiziraju poslovanje, angažiraju i vode ljude te kontroliraju raspoložive resurse. Menadžeri ostvaruju svoje ciljeve angažiranjem drugih u izvršavanju radnih zadataka i pritom motiviraju sudionike u cilju unapređenja ukupne efektivnosti i efikasnosti poslovnog sustava (Buble, 2006, 6). Menadžeri su odgovorni za postizanje ravnoteže između efektivnosti i efikasnosti. Efikasni menadžeri žele riješiti problem i reducirati troškove, a efektivni menadžeri žele kreaciju produktivnih alternativa i porast outputa (Reddin, 1989). Efektivni menadžeri su aktivni vođe koji kreiraju pozitivnu radnu okolinu u kojoj poslovni sustav i njegovi zaposlenici imaju mogućnosti i poticaje za ostvarenje visoke razine performansi (Bateman i Zeithaml, 1993).

Sustav upravljanja u lokalnoj samoupravi u Republici Hrvatskoj uređuje Zakon o sustavu unutarnjih kontrola u javnom sektoru. Naime, ovaj zakon uređuje sustav unutarnjih kontrola čija je svrha poboljšanje i unapređenje upravljanja radi postizanja općih ciljeva: obavljanje poslovanja na pravilan, etičan, ekonomičan, učinkovit i djelotvoran način, usklađenost poslovanja sa zakonima, zaštita sredstava od gubitaka, zlouporabe i štete, te jačanje odgovornosti za ostvarenje poslovnih ciljeva. Međutim, u njegovoj primjeni se pojavljuju nepravilnosti koje će se istražiti u okviru analize funkcija upravljanja u gradu Kastvu.

Menadžeri koriste različite vještine kako bi izvršavali funkcije upravljanja, a svi poslovi menadžera nisu jednaki jer su različiti menadžeri odgovorni za različita područja rada i zauzimaju pozicije na različitim razinama organizacijske hijerarhije. Razlika u poslovima menadžera se manifestira u njihovom djelokrugu 
odgovornosti. Temeljna odgovornost gradonačelnika, općinskih načelnika i njihovih zamjenika se manifestira u komuniciranju zajedničke vizije, postavljanju ciljeva, definiranju strategije za ostvarenje ciljeva, oblikovanju organizacijske kulture, nadzoru i interpretaciji eksterne okoline te donošenju odluka koje imaju utjecaja na JLPRS kao cjelinu. Zakon o lokalnim izborima ${ }^{2}$ propisuje da za općinskog načelnika, gradonačelnika, župana i njihovog zamjenika ima pravo biti biran birač koji na dan stupanja na snagu odluke o raspisivanju izbora ima najmanje šest mjeseci prijavljeno prebivalište na području JLPRS u kojoj se provodi izbor. Zakon o lokalnoj i područnoj (regionalnoj) samoupravi ${ }^{3}$ također ne propisuje uvjete koje bi morali zadovoljiti kandidati za općinske načelnike, gradonačelnike i njihove zamjenike.

Slijedom toga za javne menadžere najviše razine mogu biti izabrane osobe koje nemaju potrebne konceptualne i tehničke vještine. Iako se biraju političkim putem, općinski načelnici ili gradonačelnici moraju imati potrebne strategijske i tehničke vještine kako bi efikasno obavljali specifične funkcije upravljanja. Zakonodavac bi morao propisati opće uvjete koje bi morali zadovoljiti kandidati za općinske načelnike, gradonačelnike i njihove zamjenike jer su odgovorni za strateško usmjeravanje gradova i općina te kreiranje razvojnih politika. Uza sve to, kandidati za javne menadžere najviše razine moraju imati sljedeće ključne osobine: poštenje i integritet, kognitivne sposobnosti, razumijevanje posla te motiviranost za vođenje.

Menadžere na srednjoj razini čine pročelnici upravnih odjela koji su odgovorni za implementaciju cjelokupne strategije i politike koju su definirali javni menadžeri na najvišoj razini. Pročelnici upravnih odjela predstavljaju funkcijske menadžere jer su odgovorni za upravne odjele koji izvršavaju funkcijske zadatke. U kontekstu svega toga, pročelnici upravnih odjela bi morali razviti potrebne tehničke vještine koje se ogledaju u vladanju znanjima koja se odnose na specifične zadatke upravnih odjela i na funkcije upravljanja. S obzirom na to pročelnik upravnog odjela za financije mora imati odgovarajuće obrazovanje i tehničke vještine iz znanstvenih grana financija i upravljanja, a pročelnik upravnog odjela za prostorno uređenje i komunalni sustav mora imati odgovarajuće obrazovanje iz znanstvenih polja arhitekture i urbanizma ili građevinarstva te iz znanstvene grane upravljanja. Pročelnik jedinstvenog upravnog odjela mora imati odgovarajuće obrazovanje iz određenih područja rada jedinstvenog upravnog odjela $i$ znanstvene grane upravljanja.

Zakon o lokalnim izborima, Narodne novine, br. 144/12, 121/16

Zakon o lokalnoj i područnoj (regionalnoj) samoupravi, Narodne novine, br. 33/01, 60/01, $129 / 05,109 / 07,125 / 08,36 / 09,150 / 11,144 / 12,19 / 13,137 / 15,123 / 17$ 
Zakon o službenicima i namještenicima u lokalnoj, područnoj i regionalnoj samoupravi ${ }^{4}$ propisuje posebne uvjete za imenovanje pročelnika upravnih odjela: odgovarajuća stručna sprema i struka te uvjet radnog iskustva ostvarenog na poslovima odgovarajuće stručne spreme i struke. Međutim, kako bi se izvršila uspješna selekcija pročelnika upravnih odjela potrebne su sljedeće pretpostavke: identificiranje poslova pročelnika i utvrđivanje osobina neophodnih za posao pročelnika koje uključuju znanja, vještine i kompetencije. Prema tome, osobe koje vrše selekciju pročelnika moraju imati odgovarajuće tehničke vještine $\mathrm{i}$ znanja kako bi mogle identificirati poslove pročelnika i utvrditi osobine koje su neophodne za posao pročelnika. Definitivnu odluku o selekciji kandidata mora donijeti menadžment područja poslova za koje se kandidat bira (Buble, 2006, 400). U kontekstu svega iznesenog, može se ustvrditi kako u sustavu lokalne samouprave najčešće nema javnih menadžera najviše razine koji poznaju područje poslova za koje se pročelnik bira jer za gradonačelnike, općinske načelnike i njihove zamjenike imaju pravo biti izabrani birači koji na dan stupanja na snagu odluke o raspisivanju izbora imaju najmanje šest mjeseci prijavljeno prebivalište na području JLPRS. Prema tome, zakonodavac bi trebao propisati posebne uvjete za odabir pročelnika upravnih odjela, odnosno odgovarajuću stručnu spremu i struku uz definiranje znanstvenog polja i znanstvene grane.

Koontz i Weihrich determiniraju pet funkcija menadžmenta: planiranje, organiziranje, upravljanje ljudskim resursima, vođenje i kontroliranje (Koontz i Weihrich, 1994). Planiranje javnih menadžera najviše razine u sustavu lokalne samouprave sadrži dijagnozu poslovnog položaja, definiranje misije i zajedničke vizije, određivanje pravaca djelovanja, postavljanje ciljeva, strategiju za ostvarenje ciljeva i donošenje odluka. Zakon o sustavu unutarnjih kontrola u javnom sektoru propisuje da općinski načelnik ili gradonačelnik treba definirati jasnu misiju, viziju i poslovne ciljeve te stil upravljanja. Javni menadžeri najviše razine koji nisu razvili odgovarajuće strategijske i stručne vještine ne mogu izvršavati funkciju planiranja.

Organiziranje uključuje izbor odgovarajuće organizacijske strukture, sustava upravljanja i odnosa u poslovnom sustavu. Stoga organiziranje u sustavu lokalne samouprave predstavlja proces oblikovanja i grupiranja poslova u organizacijske jedinice kojima se može upravljati, proces raspodjeljivanja ljudi i alociranja resursa radi ostvarivanja postavljenih ciljeva (Dujanić, 2006). Projektiranje organizacije se može definirati kao proces izgradnje organizacijske strukture, a cilj je projektiranja uspostaviti optimalnu organizaciju koja će omogućiti uspješno poslovanje (Dujanić, 2006, 24).

4 Zakon o službenicima i namještenicima u lokalnoj i područnoj (regionalnoj) samoupravi, Narodne novine, br. 86/08 
Zakon o sustavu unutarnjih kontrola u javnom sektoru propisuje da općinski načelnik ili gradonačelnik treba definirati unutarnje organizacijsko ustrojstvo, dodjelu ovlasti i odgovornosti za ostvarivanje poslovnih ciljeva. Temelj uspostave sustava financijskog upravljanja i kontrola predstavljaju poslovni procesi koji se moraju pravilno utvrditi, a organizacijske jedinice se oblikuju tako da se poslovni procesi i aktivnosti grupiraju u adekvatne cjeline. Grupiranje poslovnih procesa se temelji na povezivanju istorodnih ili sličnih procesa u organizacijsku jedinicu, a pri grupiranju procesa se $u$ istu organizacijsku jedinicu mogu svrstati i različiti procesi koji su međusobno povezani ili uvjetovani. U kontekstu svega izloženog JLPRS se moraju transformirati u procesno orijentiranu organizaciju u službi građana. Unutarnje organizacijsko ustrojstvo mogu definirati samo javni menadžeri koji su razvili potrebne konceptualne i tehničke vještine te imaju stručna znanja o poslovnim procesima koji se izvršavaju u JLPRS.

Upravljanje ljudskim resursima u sustavu lokalne samouprave ima zadatak uloge određene organizacijom dodijeliti službenicima koji će ih najbolje izvršavati. Upravljanje ljudskim resursima i selekciju kadrova u sustavu lokalne samouprave nedostatno propisuje Zakon o službenicima i namještenicima u lokalnoj, područnoj i regionalnoj samoupravi. Međutim, u JLPRS za općinskog načelnika, gradonačelnika i njihove zamjenike mogu biti izabrani i kandidati čije su konceptualne i tehničke vještine insuficijentni što može rezultirati selekcijom nestručnih kadrova prema kriterijima političke vjernosti, a ne prema stručnim kvalitetama. Vođenje predstavlja funkciju upravljanja u kojoj je potrebno usmjeriti sve sudionike poslovnih procesa prema željenom cilju. Zakon o sustavu unutarnjih kontrola u javnom sektoru propisuje da javni menadžeri najviše razine trebaju definirati stil upravljanja i rukovođenja, uspostaviti sustav informacija i komunikacije koji će osigurati pravodobne i odgovarajuće informacije rukovoditeljima radi ekonomičnog, učinkovitog i djelotvornog upravljanja. Općinski načelnici, gradonačelnici i njihovi zamjenici koji nemaju odgovarajuća znanja i vještine ne mogu izvršavati funkciju vođenja.

Kontroliranje u sustavu lokalne samouprave obuhvaća mjerenje ostvarenja izabranih ciljeva i poduzimanje korektivnih akcija da se ti ciljevi ostvare. Temeljne funkcije učinkovitog kontroliranja uključuju: postavljanje standarda performansi, mjerenje aktualnih performansi u odnosu na standardne i poduzimanje korektivnih mjera gdje je to primjereno (Buble, 2006, 13). Zakon o sustavu unutarnjih kontrola $\mathrm{u}$ javnom sektoru propisuje da odgovorna osoba treba uspostaviti upravljanje rizicima i poduzimati potrebne mjere radi smanjenja rizika te da se kontrole uspostavljaju kao prethodne i naknadne kontrole. Prethodne kontrole su usmjerene na osiguranje zakonitosti i pravilnosti financijskih i drugih odluka prije donošenja odluka, odnosno prije odlučivanja o korištenju proračunskih sredstava i tijekom realizacije financijskih i drugih odluka do faze plaćanja. Naknadne 
kontrole su usmjerene na osiguranje zakonitog, svrhovitog i pravodobnog prikupljanja i korištenja proračunskih sredstava, ostvarivanja očekivanih rezultata te otkrivanja mogućih pogrešaka i nepravilnosti. Općinski načelnici, gradonačelnici i njihovi zamjenici koji nisu razvili potrebne konceptualne i tehničke vještine ne mogu izvršavati funkciju kontroliranja.

\subsection{Problemi agenata u sustavu lokalne samouprave}

Prema Jensen i Meckling okviru (1976) odnos agenata se može definirati kao ugovorni odnos u kojem jedna ili više osoba (principali) angažiraju drugu osobu (agenta) da obavlja poslove za njih što uključuje i delegiranje donošenja odluka. S obzirom da obje strane nastoje maksimizirati svoje koristi, može se pretpostaviti da agenti neće uvijek djelovati u skladu s interesima principala. Problemi agenata se mogu pojaviti u sustavu lokalne samouprave kad određene interesne skupine (općinski načelnik, gradonačelnik ili zamjenici) vode poslove za druge interesne skupine (građane) te ako jedna interesna skupina forsira svoje interese na račun druge interesne skupine (građana). Stoga problemi agenata mogu predstavljati ozbiljnu prijetnju uspješnom upravljanju u sustavu lokalne samouprave. Problemi agenata u sustavu lokalne samouprave mogu poprimiti različite oblike, npr. da javni menadžeri i službenici koriste proračunska sredstva u skladu s privatnim interesima, kao što su odlazak na službeno putovanje u inozemstvo radi ostvarivanja privatnih interesa te obavljanje poslova za privatnu tvrtku uz pomoć prijenosnog računala za vrijeme radnog vremena u JLPRS. U sustavu lokalne samouprave problemi agenata mogu poprimiti i oblike velikih razmjera kad javni menadžeri i službenici plasiraju proizvode i usluge svojih privatnih tvrtki pri nabavi i izgradnji javnih objekata.

Problemi agenata mogu prouzročiti signifikantne troškove agenata za proračun u iznosu isplaćenih sredstava za službena putovanja radi ostvarivanja privatnih interesa i rashoda za kompenzacije javnom menadžeru ili službeniku iako je za vrijeme radnog vremena obavljao poslove privatne tvrtke. Troškovi agenata se mogu povećati ustrojavanjem bespotrebnih radnih mjesta savjetnika ili odabirom nedostatno obrazovanih pročelnika upravnih odjela. U kontekstu svega izloženog, može se ustvrditi kako u točki u kojoj troškovi agenata poprimaju oblike rezidualnog gubitka, koji proizlazi iz razilaženja između aktualnih odluka javnog menadžera u vlastitom interesu i odluka koje bi maksimizirale koristi građana, pojavljuje se rizik prelaska problema agenata u koruptivne aktivnosti. Prema Aras (2007) korupcija se već u primitivnim plemenima očituje u posebnim uslugama što ih pripadnik plemena čini plemenskim vođama dok mu oni zauzvrat daju usluge drugog tipa, odnosno bolji položaj u hijerarhiji koji donosi materijalni ili kakav drugi probitak. Službenicima koji sudjeluju u koruptivnim aktivnostima bi trebao prestati radni odnos u sustavu lokalne samouprave. 
Brojni su znanstvenici istraživali rizike pojave korupcije i učinke korupcije u javnom sektoru (Budak 2006, 2016; Sljepčević et al. 2018, Derenčinović, 2001; Kregar, 1997; Grubiša, 2010; Aras, 2007). Derenčinović (2001) smatra da je korupcija proces u kojem najmanje dvije osobe nedopuštenom razmjenom u cilju ostvarivanja vlastitih probitaka postupaju na štetu javnog interesa, koristeći moralnu i pravnu normu povređuju temelje demokratskog razvoja, pravnu državu i vladavinu prava. Kregar (1997) smatra da korupcija uzrokuje pad kvalitete javnih službi, unosi nepredvidljivost u političkom odlučivanju i pravnoj regulaciji, podiže transakcijske troškove, potiče rasipanje sredstava te potiče negativnu selekciju za vodeće položaje u javnim službama.

Prema Aras (2007) u sustavu lokalne samouprave mogu se pojaviti sljedeći pojavni oblici korupcije: ugovaračka korupcija i politička korupcija. Ugovaračka korupcija predstavlja posljedicu sklapanja štetnih ugovora, dodjele koncesija, građevinskih radova, statusa nabavljača roba ili izvršitelja usluga uz ugovaranje provizije, nepoštivanja redovnog postupka u svezi dodjele tih poslova na teret proračunskih sredstava, izigravanja javnih natječaja i sl. Prema Budak (2016) u javnoj nabavi su potencijalno sukobljeni javni i privatni interes. Razmatrajući sukob privatnog interesa, za područje javne nabave važnije je promatrati djelatnike javne uprave kao agente koji imaju diskrecijsku moć za zlouporabe dodijeljene im ovlasti u privatnu korist, a prema Svjetskoj banci svaka zlouporaba javnih ovlasti u privatnu korist smatra se korupcijom.

Budak (2016) smatra da je područje javne nabave iznimno osjetljivo na korupciju, a korupcija poskupljuje javnu nabavu i vodi ka suboptimalnoj alokaciji resursa. Korupcijska renta funkcionira kao dodatni porez koji se bilo u postotku ugovorene vrijednosti ili rjeđe kao fiksni iznos plaća djelatniku javne uprave, dok za ponuditelje korupcijski iznos predstavlja trošak koji će uračunati u ponuđenu cijenu predmeta javne nabave. $U$ taj trošak uračunati su i rizici od neobavljenog posla, otkrivanja i sankcioniranja. Ponuditelj minimizira rizik neobavljenog posla često ugovarajući isplatu provizije po zaključenju ugovora. S porastom rizika da bude otkriven, rastu i transakcijski troškovi korupcije kao ilegalne aktivnosti, korupcijski aranžman postaje složeniji i potrebno je naći rafinirane modalitete njegove provedbe. Ponuditelj često mora uložiti znatne resurse kako bi u posao uključio posrednike, otvorio novo poduzeće ili bankovni račun, obavio niz financijskih transakcija u zemlji i inozemstvu, o čemu valja voditi dvojnu evidenciju, izraditi dodatnu dokumentaciju i drugo. Visoki ukupni troškovi korupcije koji obuhvaćaju direktne troškove korupcijske rente $\mathrm{i}$ indirektne troškove korupcijske transakcije u pozitivnoj su vezi s vrijednosti javnog ugovora. U konačnici se za iznos korupcije iz javnih fondova plaća uvećana vrijednost ugovora (Budak, 2016). 
Politička korupcija se može definirati kao zlouporaba političke moći za osobne ili pristrane političke interese (Grubiša, 2010). Prema Budak (2006) politička korupcija je prisutna među dužnosnicima i političarima koji imaju pravo donošenja političkih odluka, odnosno povjerene ovlasti iz kojih proizlazi i velika odgovornost da će pri obnašanju dužnosti zastupati javne interese.

Model znanstvenog upravljanja javnom upravom je bila antikorupcijska strategija koja je predstavljala poveznicu između korupcije u javnom i privatnom sektoru i koja je inicirala sveobuhvatnije modele borbe protiv korupcije. Ova strategija je pristupila problemu korupcije u javnoj upravi kao problemu u oblikovanju same organizacije pa je neprikladnu strukturu uprave trebalo izmijeniti i utemeljiti novu upravu na načelima znanstvenog upravljanja javnim sektorom (Derenčinović, 2001).

Smatra se bitnim istaknuti kako bi zakonodavac morao ograničiti ponašanje djelatnika javnog sektora i njihovo djelovanje u suprotnosti s interesima građana uspostavljanjem odgovarajućih mehanizama i provođenjem nadzora nad njihovim aktivnostima s ciljem sprečavanja problema agenata koji predstavljaju ozbiljnu prepreku uspješnom upravljanju u javnom sektoru.

\subsection{Pregled dosadašnjih istraživanja upravljanja u sustavu lokalne samouprave}

Postoje brojna istraživanja upravljanja i financijskog upravljanja u sustavu lokalne samouprave (Lamza-Maronić et al., 2006; Bogović, 2014; Budimirović, 2017; Koprić, 2018; Lozina i Jerkić, 2018; Kontuš, 2012, 2013). Lamza-Maronić et al. (2006) su istražili stanje menadžmenta u lokalnoj samoupravi grada Vinkovaca i grada Vukovara. Provedena je anketa kako bi se spoznalo što bi motiviralo zaposlene i kakva je kvaliteta komunikacije u gradskoj upravi. U uzorak je uključen ukupan broj zaposlenih u gradu Vinkovcima i gradu Vukovaru. Rezultati istraživanja su pokazali da pored kontinuiranih ulaganja u informacijsko-komunikacijsku tehnologiju postoji potreba za kontinuiranim ulaganjem u obrazovanje zaposlenika uprave. Bez adekvatnog znanja zaposlenika, ulaganja sredstava poreznih obveznika u informacijsko-komunikacijsku tehnologiju kratkoročno i dugoročno postaju promašena investicija. Isto tako rezultati istraživanja su pokazali da uvođenje informacijsko-komunikacijskih tehnologija omogućava povećanje učinkovitosti i smanjenje troškova, povećanje odgovornosti i smanjenje korupcije te jačanje demokratske participacije.

Budimirović (2017) smatra da se problemi u upravljanju u sustavu lokalne samouprave mogu pojaviti zbog nestručnosti i nedostatka kompetencija gradonačelnika 
i njihovih zamjenika jer za lokalne menadžere, kao što su gradonačelnici i njihovi zamjenici, nisu propisane potrebne kvalifikacije i radno iskustvo. Lozina i Jerkić (2018) su istražili stanje lokalne i područne samouprave u Republici Hrvatskoj s posebnim osvrtom na stanje u Splitsko-dalmatinskoj županiji te su ustvrdili da su lokalna i područna samouprava važna karika u višerazinskom modelu upravljanja i odlučivanja. Isto tako su pokazali da lokalna i područna samouprava ovisi o nizu determinanti kao što su financijski, politički, povijesni, kulturološki, demografski, prometni i drugi čimbenici. Koprić (2018) je ustvrdio da se gradovima posvećuje sve veća pozornost kao generatorima razvoja šireg okolnog prostora i širi se suradnja različitih razina vlasti te višerazinsko (multi-level) upravljanje.

Menadžment predstavlja proces rada s drugima i pomoću drugih na ostvarenju organizacijskih ciljeva u promjenjivoj okolini uz efektivnu i efikasnu uporabu ograničenih resursa (Kreitner,1989). Proračunska sredstva koja se koriste u poslovnim procesima u sustavu lokalne samouprave su ograničena pa je nužno da javni menadžeri svih razina osiguraju efektivno i efikasno korištenje ograničenih sredstava. Financijsko upravljanje u sustavu lokalne samouprave predstavlja usmjeravanje i kontroliranje financijskih učinaka poslovanja radi ostvarenja poslovnih ciljeva, koristeći pritom proračunska sredstva na pravilan, etičan, djelotvoran i ekonomičan način. Javni menadžeri u sustavu lokalne samouprave moraju dodjeljivati i upotrebljavati ograničena proračunska sredstva odgovorno, učinkovito i efikasno u cilju ostvarivanja performansi koje poprimaju maksimalne vrijednosti. Financijski menadžment u JLPRS uključuje: determiniranje fiskalne politike, pripremu proračuna i povezivanje rashoda proračuna s rezultatima koji se ostvaruju kroz definirane programe na lokalnoj i regionalnoj razini te upravljanje financijskim operacijama u skladu sa strategijskim ciljevima radi osiguranja regionalnog i lokalnog razvoja (Kontuš, 2013,341). S ciljem osiguranja regionalnog i lokalnog razvoja jedinice lokalne, područne i regionalne samouprave mogu izgraditi infrastrukturne objekte uz korištenje tradicionalnog javnog financiranja. Zbog ograničenih proračunskih sredstava osnovni cilj javnih menadžera najviše razine treba biti osiguranje aktivnog sudjelovanja privatnog sektora u financiranju i upravljanju infrastrukturnim projektima (Kontuš, 2012, 122).

Bogović (2014) je proveo istraživanje efikasnosti korištenja javnih resursa u ostvarivanju određenih učinaka na ekonomske performanse društvenog razvoja, kao mjere učinkovitosti upravljanja u gradovima u Republici Hrvatskoj. Istraživanje je provedeno na uzorku od petnaest velikih gradova u Republici Hrvatskoj, a u istraživanju je korištena metoda analize omeđivanja podataka. Rezultati istraživanja su ukazali kojim se gradovima učinkovito upravlja te koje resurse javni menadžeri u neučinkovitim gradovima trebaju efikasnije koristiti i koje rezultate moraju postizati da bi postali učinkoviti. Učinkoviti gradovi (Vinkovci, Velika Gorica, Slavonski Brod, Pula, Dubrovnik i Varaždin) su istaknuti kao primjeri 
dobre prakse upravljanja. Prosječna relativna učinkovitost upravljanja velikim gradovima u Republici Hrvatskoj iznosi 87,67\% što znači da u prosjeku lokalni politički menadžment mora postizati $14 \%$ bolje rezultate s istim resursima da bi bio učinkovit. Najveći utjecaj na loše rezultate neučinkovitih gradova imala je visoka stopa nezaposlenosti i niske investicije po zaposlenom.

U cilju postizanja konkurentnosti i zadovoljavanja potreba širih interesnih skupina, gradonačelnici i njihovi zamjenici su prinuđeni ponašati se odgovorno radi što učinkovitijeg upravljanja razvojnim potencijalima grada. Provedeno istraživanje je pokazalo da je moguće standardizirati metodologiju ocjenjivanja učinkovitosti javnog sektora u Republici Hrvatskoj koristeći analizu omeđivanja podataka kao koristan i primjenjiv menadžerski alat za upravljanje javnim sektorom i ocjenu uspješnosti političkog menadžmenta. Rezultati istraživanja su omogućili procjenu uspješnosti lokalnog menadžmenta u upravljanju javnim resursima i kvalitete obavljanja javnih poslova i usluga, ali su isto tako pokazali političkom menadžmentu da se metoda analize omeđivanja podataka može koristiti kao važno strateško i organizacijsko oruđe. Proces se upravljanja ne smije svesti samo na materijalne resurse nego i na intelektualni kapital koji se uspješnim vođenjem može razvijati i pozitivno utjecati na povećanje učinkovitosti, ali se isto tako pod utjecajem lošega vođe može onemogućiti u ostvarivanju visoke razine performansi (Bogović, 2014). Dosadašnja istraživanja otvaraju nova pitanja kako unaprijediti sustav upravljanja u lokalnoj samoupravi i ukazuju da su potrebna daljnja istraživanja upravljanja u sustavu lokalne samouprave.

\section{ANALIZA UPRAVLJANJA U SUSTAVU LOKALNE SAMOUPRAVE}

\subsection{Metodologija}

Istraživanje funkcija upravljanja i ostvarenih performansi u sustavu lokalne samouprave je provedeno na primjeru grada Kastva. Grad Kastav je status grada dobio zbog posebnih razloga tj. posebnog povijesnog značenja, bogate prosvjetne tradicije i kulture. Analiza strukture gradonačelnika i njihovih zamjenika koji funkcije obnašaju profesionalno prema stupnju stručne spreme je izvršena na uzorku od 113 gradova u Republici Hrvatskoj koji imaju više od 4.000 stanovnika.

Analiza ostvarenih performansi u gradu Kastvu sadrži analizu ostvarenih kapitalnih projekata koji uključuju nabavu objekata za predškolski odgoj. Izvršena je usporedba ostvarenih performansi javnih menadžera u gradu Kastvu s gradovima i općinama koji su obuhvaćeni ovim istraživanjem. U homogeni uzorak 
su uključeni sljedeći gradovi i općine: grad Požega, grad Novska, grad Osijek, grad Slavonski Brod, općina Kneginec, općina Jakšić, općina Križ i općina Sveta Nedelja koji su u razdoblju od 2015. do 2018. godine gradili javne objekte za predškolski odgoj. Primjenom deskriptivne statistike analizirane su cijene izgradnje objekata po djetetu te je izvršena usporedba cijene kupovine javnog objekta po djetetu u gradu Kastvu s rezultatima statističke analize: aritmetičkom sredinom, minimumom i maksimumom koji su ostvareni u istraživanim gradovima i općinama.

\subsection{Studija slučaja - analiza upravljanja u gradu Kastvu}

Istraživanje funkcija upravljanja u gradu Kastvu uključuje sve razine upravljanja: predstavničko tijelo, izvršno tijelo i upravne odjele. Predstavničko tijelo ima ukupno 17 vijećnika, a struktura predstavničkog tijela je prikazana u tablici 1.

Tablica 1. Struktura predstavničkog tijela Grada Kastva

\begin{tabular}{|l|c|c|}
\hline \multicolumn{1}{|c|}{ Opis } & Broj vijećnika & Udio u \% \\
\hline Koalicija SDP-a i drugih stranaka (6 stranaka) & 8 & $47,06 \%$ \\
\hline Akcija mladih & 4 & $23,53 \%$ \\
\hline Hrvatska demokratska zajednica & 4 & $23,53 \%$ \\
\hline Narodna stranka-reformisti & 1 & $5,88 \%$ \\
\hline Ukupno & 17 & $100,00 \%$ \\
\hline
\end{tabular}

Izvor: Službene stranice grada Kastva

Heterogena koalicija šest političkih stranaka je nakon provedenih izbora osnovala koaliciju s vijećnikom Narodne stranke i formirala političku većinu u predstavničkom tijelu. Funkciju predsjednika predstavničkog tijela obnaša vijećnik Narodne stranke-reformisti, čiji udio u predstavničkom tijelu iznosi 5,88\%, što se može elaborirati kao nedovoljno demokratsko i ekstremno ustrojavanje predstavničkog tijela. Analiza strukture gradonačelnika i njihovih zamjenika, koji funkcije obnašaju profesionalno, prema stupnju stručne spreme je izvršena na uzorku od 113 gradova u Republici Hrvatskoj te je izvršena usporedba grada Kastva s ostalim gradovima. Stupanj stručne spreme općinskih načelnika, gradonačelnika i njihovih zamjenika pokazuje kakve su konceptualne i tehničke vještine razvili tijekom njihovog obrazovanja. 
Tablica 2. Struktura gradonačelnika i zamjenika koji funkcije obnašaju profesionalno prema stupnju stručne spreme

\begin{tabular}{|c|c|c|}
\hline $\begin{array}{c}\text { Stupanj stručne spreme } \\
\text { Razredi }\end{array}$ & Broj gradova & $\%$ \\
\hline Dužnosnici - funkciju ne obnašaju profesionalno & 4 & 3,54 \\
\hline Tri dužnosnika VSS i više & 18 & 15,93 \\
\hline Dva dužnosnika VSS i više & 19 & 16,81 \\
\hline Jedan dužnosnik VSS & 31 & 27,43 \\
\hline Tri dužnosnika VSS, VŠS & 6 & 5,31 \\
\hline Dva dužnosnika VSS, VŠS & 8 & 7,08 \\
\hline Jedan dužnosnik VŠS & 7 & 6,19 \\
\hline Tri dužnosnika VSS, SSS & 4 & 3,54 \\
\hline Dva dužnosnika VSS, SSS & 9 & 7,96 \\
\hline Dva dužnosnika VŠS & 3 & 2,65 \\
\hline Dva dužnosnika SSS, VŠS & 1 & 0,88 \\
\hline Jedan dužnosnik SSS & 3 & 2,65 \\
\hline
\end{tabular}

Izvor: Registar dužnosnika

Rezultati istraživanja su pokazali kako $3,54 \%$ gradova ima gradonačelnike i zamjenike koji funkcije ne obnašaju profesionalno (Ivanec, Pregrada, Orahovica i Imotski). Nadalje, rezultati istraživanja strukture javnih menadžera najviše razine koji funkciju obnašaju profesionalno su pokazali sljedeće: $60,17 \%$ gradova ima javne menadžere s visokom stručnom spremom i više, $12,39 \%$ gradova ima javne menadžere $\mathrm{s}$ visokom i višom stručnom spremom, $11,5 \%$ gradova ima javne menadžere s visokom i srednjom stručnom spremom, $8,84 \%$ gradova ima javne menadžere s višom stručnom spremom, a $0,88 \%$ gradova, odnosno grad Kastav, ima gradonačelnika sa srednjom strukovnom školom SŠER ${ }^{5}$ i zamjenika s višom stručnom spremom.

Rezultati istraživanja su pokazali kako u gradu Kastvu, koji je status grada dobio zbog posebnog povijesnog značenja, bogate prosvjetne tradicije i kulture, nije potrebno da niskoobrazovani gradonačelnik i njegov zamjenik funkcije obnašaju profesionalno. Četiri grada u Republici Hrvatskoj nemaju gradonačelnika ili zamjenika koji funkciju obnašaju profesionalno, a u petnaest gradova u Republici Hrvatskoj, koji su veći od grada Kastva, samo jedan dužnosnik funkciju obnaša profesionalno. Rashodi za njihove kompenzacije predstavljaju neefikasno korištenje proračunskih sredstava. ${ }^{6}$

5 Podatci o stupnju stručne spreme dužnosnika su preuzeti iz imovinskih kartica dužnosnika. Prema članku 2. Statuta Srednje škole za elektrotehniku i računarstvo (SŠER), SŠER je javna ustanova koja obavlja djelatnost strukovnog obrazovanja u skladu s odredbama Zakona o strukovnom obrazovanju i Zakona kojim se uređuje djelatnost srednjeg obrazovanja. http:// web2.ss-elektrotehnicka-ri.skole.hr/ (pristupljeno 15.12.2018.)

$6 \quad$ Ako gradu Ivancu koji ima 13.392 stanovnika nije potrebno da gradonačelnik ili zamjenik funkciju obnašaju profesionalno, u gradu Kastvu koji ima 10.705 stanovnika nisu potrebni 
U nastavku su istražene temeljne funkcije upravljanja koje uključuju: planiranje, organiziranje, upravljanje ljudskim resursima i kontroliranje u gradu Kastvu.

\section{1) Planiranje kao funkcija upravljanja}

Javni menadžeri najviše razine moraju imati odgovarajuće strategijske vještine kako bi mogli izvršavati specifičnu funkciju planiranja u gradu Kastvu odnosno determinirati poslovni položaj grada, odrediti pravce djelovanja, postaviti ciljeve i definirati strategije za ostvarenje postavljenih ciljeva. Pročelnici upravnih odjela bi morali biti odgovorni za implementaciju cjelokupne strategije i politike koju moraju definirati javni menadžeri na najvišoj razini te za pravodobno i sustavno planiranje aktivnosti ustrojstvenih jedinica.

\section{2) Organiziranje kao funkcija upravljanja}

Organiziranje uključuje oblikovanje organizacijske strukture, sustava upravljanja i odnosa u poslovnom sustavu. Gradonačelnik, zamjenik i suradnici su u Odluci o ustrojstvu i djelokrugu rada gradskih upravnih tijela Grada Kastva aktivnosti jedanaest poslovnih procesa, koje se izvršavaju u upravnom odjelu za financije, definirali pogrešno i na nestručan način: priprema i izvršenje proračuna grada, vođenje knjigovodstva te vođenje platnog prometa putem računa grada što dokazuje da suradnici koje odabiru niskoobrazovani dužnosnici nemaju potrebna znanja niti razvijene tehničke vještine iz financija (javnih financija), financijskog menadžmenta i računovodstva te da oni ne razumiju sveobuhvatnost i složenost financijskog sustava, sustav financijskog upravljanja i kontrola te ciljeve koje je potrebno ostvariti. Rezultati istraživanja sugeriraju kako su posljedica nestručno oblikovane organizacijske strukture u gradu Kastvu nepravilno oblikovana i nepotrebna radna mjesta: savjetnik za odnose s javnošću, referent za obračun komunalnih prihoda, viši stručni suradnik za prostorno uređenje i zaštitu okoliša te radno mjesto za stručnog specijalista javne uprave. Dodjeljivanje radnih zadataka iz znanstvenog polja prava, koje bi trebali obavljati magistri prava, stručni specijalisti javne uprave ima za posljedicu ostvarivanje performansi koje signifikantno odstupaju od standarda performansi te pokretanje tužbi pred upravnim sudom i ostalim sudovima. Definirani poslovi različitih savjetnika i njihova složenost signifikantno odstupaju od složenosti poslova koje bi trebali obavljati savjetnici za određena područja rada. Službenike koji izvršavaju poslove javne nabave potrebno je rasporediti u okviru istog upravnog odjela odnosno javno nabavne službe, kako bi javno nabavna služba kontinuirano mogla tražiti optimalnu kombinaciju ukupnih troškova i kvalitete koja zadovoljava zahtjeve građana.

dvojica koji funkciju obnašaju profesionalno dok se prema stupnju stručne spreme nalaze pri samom dnu u gradovima u Republici Hrvatskoj. Gradonačelnik i njegov zamjenik koji funkcije obnašaju profesionalno u gradu Kastvu primaju kompenzacije iz proračuna za redovan rad koje su u 2017. godini iznosile 576.917,48 kuna. 
Rezultati istraživanja su pokazali kako organizacijsku strukturu u gradu Kastvu ne mogu projektirati gradonačelnik i njegov zamjenik čije je obrazovanje nisko i insuficijentno. ${ }^{7}$

\section{3) Upravljanje ljudskim resursima}

Gradonačelnik i njegov zamjenik, koji su prema rezultatima istraživanja niskoobrazovani, raspisali su natječaje za radna mjesta pročelnika koja temeljem pravne regulative nisu bila upražnjena. Povjerenstvo za provođenje natječaja za pročelnika upravnog odjela za financije se sastojalo od zamjenika gradonačelnika sa završenim dvogodišnjim studijem građevinarstva, magistra prava i magistra ekonomije koji nisu ostvarivali uvjete za pročelnika upravnog odjela za financije. ${ }^{8}$ Članovi povjerenstva koji nisu razumjeli kako ne mogu provjeravati znanja pročelnika iz znanstvenog polja ekonomije te grana financija i upravljanja, jer nemaju odgovarajuća znanja i tehničke vještine, definirali su pitanja i vrednovali odgovore na pitanja. Uza sve to, osobi koja nije ispunjavala formalne uvjete natječaja su za pogrešne odgovore dodjeljivali bodove, a osobi koja ima najbolje uvjete za pročelnika nisu dodijelili odgovarajuće bodove za ispravne odgovore. Pogrešna rang-lista u korist osobe koja nije ispunjavala niti formalne uvjete natječaja je javno objavljena. U nastavku je prikazano nekoliko pitanja i odgovora na pitanja koji potvrđuju kako je rang-lista pogrešno sastavljena. ${ }^{9}$ Gradonačelnik i njegov zamjenik, koji su niskoobrazovani, ne mogu provjeravati znanja službenika i pročelnika, ocjenjivati pročelnike te vršiti odabir službenika i pročelnika. Prema odredbama Zakona o potvrđivanju Europske povelje o lokalnoj

7 U gradu Kastvu je organizacijska struktura izmijenjena u 2016. godini, tj. u trenutku kada je kupljen prostor za predškolski odgoj, tako da je Upravni odjel za opće i pravne poslove te lokalnu samoupravu podijeljen u dva upravna odjela. U 2018. godini, odnosno samo dvadeset mjeseci nakon toga, su niskoobrazovani dužnosnici ponovo povezali ova dva odjela u jedan odjel s nazivom Ured grada, a Upravni odjel za financije je uz svojih trinaest poslovnih procesa dobio još dva poslovna procesa.

8 Zamjenik gradonačelnika sa završenim dvogodišnjim studijem iz građevinarstva je pokušao izvršiti provjeru znanja magistra znanosti iz znanstvenog polja ekonomije, iako između njegovog dvogodišnjeg studija i poslijediplomskog magistarskog znanstvenog studija postoje diplomski studij i poslijediplomski specijalistički studij, kao da znanjem i vještinom nadmašuje magistre znanosti.

9 U nastavku su prikazani odgovori na samo dva pitanja za koje su osobi koja nije ispunjavala niti formalne uvjete natječaja dodjeljivani bodovi jer se svi pogrešno vrednovani odgovori i praktični zadatak ne mogu prikazati u ovom radu:

- S Što su izvanproračunski korisnici? Odgovor: trgovačka društva, izvanproračunski fondovi i drugi pravni subjekti u kojima RH i JLPRS imaju odlučujući utjecaj u upravljanju. Upisani su u registar koji se vodi pri Ministarstvu financija.

Ispravan odgovor se može pronaći u članku 2. Zakona o proračunu (NN 15/15).

- S Što sadrži program konvergencije? Odgovor: makroekonomsku analizu, fiskalne pokazatelje.

Ispravan odgovor se može pronaći u članku 24. Zakona o proračunu (NN 15/15). 
samoupravi u tijelima lokalnih jedinica treba omogućiti zapošljavanje službenika polazeći od načela kakvoće, sposobnosti i stručnosti. ${ }^{10}$

U kontekstu svega izloženog smatra se bitnim istaknuti kako bi hrvatski zakonodavac trebao razmotriti i propisati sljedeće u okviru postojeće pravne regulative: razmotriti je li provjera znanja i sposobnosti u sustavu lokalne samouprave dovoljno efikasna ili ju je potrebno ukinuti, ${ }^{11}$ propisati stručnu spremu koju trebaju imati kandidati u obliku znanstvenog polja i znanstvene grane, ${ }^{12}$ preciznije definirati uvjet radnog iskustva ostvarenog na poslovima odgovarajuće stručne spreme i struke ${ }^{13}$ te je potrebno propisati obrazovanje koje moraju imati članovi povjerenstva koje provodi provjeru znanja. ${ }^{14}$

\section{4) Kontroliranje kao funkcija upravljanja}

Efikasno kontroliranje sadrži sljedeće: postavljanje standarda performansi, mjerenje aktualnih performansi u odnosu na standarde i poduzimanje korektivnih mjera. Mjerenje i analiza performansi javnih menadžera u gradu Kastvu su izvršeni u području nabave javnih objekata. Negativne performanse javnih menadžera mogu nastati pri rješavanju osnovnih komunalnih problema kao što je izgradnja groblja. Umjesto da se pravodobno izgradi novo groblje izvan grada, pretprostor groblja u središtu grada je pretvoren u grobna polja. Prvi dojam koji turisti stječu pri dolasku u grad determinira pogled na grobna polja te se može stvoriti pogrešna percepcija kako se radi o gradu čiji građani nisu dovoljno civilizirani, a ne o poželjnoj destinaciji turista koju je vrijedno posjetiti. Analiza ostvarenih performansi je provedena i u okviru nabave objekta za predškolski odgoj

10 Niskoobrazovani gradonačelnik i njegov zamjenik su pokušali imenovati za pročelnika službenika koji ne ostvaruje niti formalne uvjete umjesto službenika koji ima najviši akademski stupanj iz znanstvenog polja ekonomije, odgovarajuće radno iskustvo i koji je razvio financijski sustav grada te koji ostvaruje i uvjet istaknutih rezultata rada u području od značaja za rad državnih tijela. Odabir službenika i pročelnika koji ne ostvaruju niti formalne uvjete ili koji ne ostvaruju najbolje uvjete predstavlja selekciju prema kriterijima političke vjernosti.

11 Lokalni dužnosnici mogu zloupotrijebiti provjeru znanja kako bi zaposlili kandidate po kriterijima političke vjernosti te im dodijeliti pitanja prije provođenja provjere znanja.

12 Kadrovi koji su završili studij međunarodne ekonomije ili razredne nastave nisu odgovarajući kadrovi za zapošljavanje u sustavu lokalne samouprave jer između lokalne samouprave i međunarodne ekonomije odnosno razredne nastave nema nikakve povezanosti, dok su kadrovi sa završenim specijalističkim studijem poslovanje s Europskom unijom neophodni u svakoj JLPRS.

13 Niskoobrazovani dužnosnici nemaju razvijene tehničke vještine iz grana financija i računovodstva, javnih financija te ne razumiju da knjigovodstveni poslovi ne predstavljaju radno iskustvo na poslovima odgovarajuće stručne spreme za radno mjesto pročelnika UO za financije.

14 Niskoobrazovani dužnosnici ne razumiju da provjeru znanja mogu provoditi samo članovi povjerenstva čiji su obrazovanje i vještine više razine u odnosu na kandidate čija se znanja i sposobnosti provjeravaju te koji imaju znanja iz određenog znanstvenog polja i znanstvene grane. 
te je izvršena usporedba s ostalim gradovima i općinama. Rezultati istraživanja nabave objekta za predškolski odgoj u gradu Kastvu su prikazani u tablici 3.

Tablica 3. Nabava objekta za predškolski odgoj u gradu Kastvu

\begin{tabular}{|c|c|}
\hline Opis & Iznos u kunama (bez PDV-a) \\
\hline Nabavna vrijednost & $10.701 .841,22$ \\
\hline Broj djece & 100 \\
\hline Nabavna vrijednost po djetetu & $107.018,41$ \\
\hline
\end{tabular}

Izvor: Službene stranice grada Kastva

Grad Kastav je kupio prostor za predškolski odgoj za smještaj 100 djece od privatnog investitora uz cijenu od 10.701.841,22 kune bez PDV-a te je ostvario nabavnu vrijednost po djetetu koja iznosi 107.018,41 kuna. U Tablici 4. su prikazane ukupne cijene izgradnje objekata za predškolski odgoj bez PDV-a i cijene izgradnje objekata po djetetu u gradovima i općinama koji su obuhvaćeni ovim istraživanjem. Cijene izgradnje predstavljaju ugovorene cijene izgradnje nakon provođenja otvorenog postupka javne nabave ili cijene izgradnje iz izvještaja o izvršenju proračuna za objekte koji su izgrađeni.

Tablica 4. Nabava objekata za predškolski odgoj u ostalim JLPRS - deskriptivna statistika

\begin{tabular}{|l|c|c|c|}
\hline \multicolumn{1}{|c|}{$\begin{array}{c}\text { Opis } \\
\text { Grad/ Općina }\end{array}$} & $\begin{array}{c}\text { Cijena izgradnje bez } \\
\text { PDV-a (kuna) }\end{array}$ & Broj djece & $\begin{array}{c}\text { Cijena izgradnje } \\
\text { Po djetetu (kuna) }\end{array}$ \\
\hline grad Novska & $4.700 .000,00$ & 100 & $47.000,00$ \\
\hline grad Osijek & $8.000 .000,00$ & 120 & $66.666,67$ \\
\hline grad Požega & $9.256 .427,57$ & 200 & $46.282,14$ \\
\hline $\begin{array}{l}\text { grad Slavonski Brod } \\
\text { D.V.Tintilinić - 2015.g. }\end{array}$ & $3.200 .000,00$ & 74 & $43.243,24$ \\
\hline $\begin{array}{l}\text { grad Slavonski Brod } \\
\text { D.V.Potjeh - 2017.g. }\end{array}$ & $3.537 .592,01$ & 77 & $45.942,75$ \\
\hline općina Gornji Kneginec & $9.907 .325,14$ & 200 & $49.536,63$ \\
\hline općina Jakšić & $4.800 .000,00$ & 75 & $64.000,00$ \\
\hline općina Križ & $7.045 .520,00$ & 140 & $50.325,14$ \\
\hline općina Sveta Nedelja & $3.339 .620,00$ & 72 & $46.383,61$ \\
\hline Aritmetička sredina & & & $50.642,92$ \\
\hline Standardna devijacija & & & $8.548,69$ \\
\hline Minimum & & & $43.243,24$ \\
\hline Maksimum & & & $66.666,67$ \\
\hline
\end{tabular}

Izvor: Službene stranice gradova i općina 
Rezultati statističke analize su pokazali kako je aritmetička sredina cijena izgradnje objekata za predškolski odgoj po djetetu u vremenskom razdoblju od 2015. do 2018. godine iznosila 50.642,92 kune. Minimalna cijena izgradnje po djetetu je iznosila 43.243,24 kune, a maksimalna cijena izgradnje po djetetu je iznosila 66.666,67 kuna. U nastavku je prikazana usporedna analiza cijene kupovine objekta po djetetu i cijena izgradnje objekata za predškolski odgoj po djetetu (Tablica 5).

Tablica 5. Usporedna analiza nabavnih cijena objekata za predškolski odgoj po djetetu

\begin{tabular}{|c|c|}
\hline Opis & Iznos u kunama \\
\hline Cijena kupovine objekta po djetetu & \\
\hline grad Kastav & $107.018,41$ \\
\hline $\begin{array}{c}\text { Cijena izgradnje objekata po djetetu - } \\
\text { ostali gradovi i općine }\end{array}$ & \\
\hline Aritmetička sredina & $50.642,92$ \\
\hline Minimum & $43.243,24$ \\
\hline Maksimum & $66.666,67$ \\
\hline
\end{tabular}

Izvor: obrada autora

Rezultati statističke analize su pokazali kako je cijena kupovine po djetetu, koju je ostvario Grad Kastav, veća od prosječne cijene izgradnje po djetetu koju su ostvarili ostali gradovi i općine za $111,32 \%$, dok je od minimalno ostvarene cijene veća za $147,48 \%$, a od maksimalno ostvarene cijene je veća za $60,53 \%$. U kontekstu svega izloženog može se ustvrditi: da je grad Kastav izgradio objekt za predškolski odgoj i smještaj 100 djece prema maksimalnoj cijeni izgradnje po djetetu, koju su ostvarili ostali gradovi i općine, mogao je izgraditi objekt za 6,7 milijuna kuna, a da je ostvario prosječnu cijenu izgradnje po djetetu mogao ga je izgraditi za 5,1 milijuna kuna bez PDV-a. Rezultati istraživanja pokazuju kako razlika između cijene kupovine prostora za predškolski odgoj koju je ostvario grad Kastav i cijene gradnje koju je mogao ostvariti da je objekt izgradio prema maksimalno ostvarenoj cijeni gradnje iznosi četiri milijuna kuna. Razlika između cijene kupovine i cijene gradnje koju je mogao ostvariti da je objekt izgradio prema prosječnoj cijeni gradnje iznosi 5,6 milijuna kuna bez PDV-a. Smatra se bitnim istaknuti sačinjava li razlika od četiriju ili 5,6 milijuna kuna zaradu koju je ostvario privatni investitor, a o kojoj je na sjednici Gradskog vijeća govorio bivši vijećnik koji se trenutno nalazi na poziciji gradonačelnika. ${ }^{15}$ Potrebno je ustvrditi

15 Bivši vijećnik, koji se trenutno nalazi na poziciji gradonačelnika, je na 23. sjednici Gradskog vijeća od 30. srpnja 2015. godine govorio: „... Normalno da investitor mora imati neku matematiku, neće raditi objekt da ostane praznih ruku i u minusu. ... Mislim da je ta cijena ne odličan posao za grad, nego fantastičan.“ Bivši (sadašnji) vijećnik oporbe je govorio:““... Investitor je to izgradio za manje. Dakle i mi to možemo izgraditi za manje. ... Cijena gradnje je manja od cijene kupljenog prostora..." Ovi navodi su preuzeti iz Zapisnika s 23. sjednice Gradskog vijeća održane 30. srpnja 2015. godine koji je objavljen na Službenim stranicama grada Kastva u 
kako sudionici u nabavi javnih objekata, koji se financiraju iz tradicionalnih proračunskih sredstava ili dugoročnim zaduživanjem, ne smiju ostvariti dobit niti druge oblike zarade. U isto vrijeme, to što je privatni investitor kupio zemljište i uplatio ugovorenu cijenu ne predstavlja aktivno sudjelovanje privatnog investitora $\mathrm{u}$ financiranju nabave javnog objekta jer je privatni investitor za uplaćene iznose dobio vrijedno zemljište. Rezultati istraživanja provedenog u ovom radu sugeriraju kako ostvarena signifikantna razlika pri kupovini javnog objekta od privatnog investitora može predstavljati izazovno područje za daljnja istraživanja Državnog odvjetništva Republike Hrvatske.

Uza sve to, rezultati istraživanja kompenzacija javnih menadžera najviše razine su pokazali kako gradonačelnik grada Rovinja, koji je završio poslijediplomski doktorski studij i osvojio 2.069 glasova više u odnosu na protukandidate, prima neto plaću u iznosu od 13.191,19 kuna, a gradonačelnik grada Kastva koji je završio srednju strukovnu školu i osvojio 39 glasova više u odnosu na protukandidate prima neto plaću u iznosu $12.123,81$ kune.${ }^{16}$ Zamjenik gradonačelnika grada Rovinja, koji funkciju obnaša profesionalno i ima visoku stručnu spremu, prima neto plaću u iznosu od 8.758,10 kuna, a zamjenik gradonačelnika grada Kastva, koji funkciju obnaša profesionalno i ima višu stručnu spremu, prima neto plaću u iznosu 11.293,73 kune. ${ }^{17}$ Rezultati istraživanja kompenzacija javnih menadžera najviše razine su pokazali kako gradonačelnik sa srednjom strukovnom školom u gradu Kastvu generira rashode za plaće skoro kao gradonačelnik grada Rovinja koji je stekao akademski stupanj doktora znanosti, a zamjenik gradonačelnika s višom stručnom spremom, koji funkciju obnaša profesionalno u gradu Kastvu, generira rashode za plaće signifikantno veće nego zamjenik gradonačelnika s visokom stručnom spremom u gradu Rovinju.

Rashodi za kompenzacije javnih menadžera najviše razine predstavljaju neracionalno i neefikasno trošenje proračunskih sredstava zbog njihovog niskog obrazovanja i zato jer u Republici Hrvatskoj ima većih gradova koji nemaju gradonačelnika ili zamjenika koji funkciju obnaša profesionalno (grad Ivanec) dok petnaest većih gradova ima jednog dužnosnika koji funkciju obnaša profesionalno. ${ }^{18}$

privitku Poziva za 24. sjednicu Gradskog vijeća. Izvor: https//www.kastav.hr/ (pristupljeno 15. 11.2018.)

16 Podatci o bruto i neto plaćama su preuzeti iz imovinskih kartica dužnosnika. Ukupni prihodi proračuna grada Rovinja su iznosili u 2017. godini 151.518.754 kune, a ukupni prihodi grada Kastva su iznosili 51.580.002 kuna.

17 Bruto plaća zamjenika gradonačelnika, koji funkciju obnaša profesionalno i ima visoku stručnu spremu, u gradu Rovinju iznosi 13.062,36 kuna, a bruto plaća zamjenika gradonačelnika, koji funkciju obnaša profesionalno i ima višu stručnu spremu, u gradu Kastvu iznosi 15.397,59 kuna.

18 Rashodi za plaće, poreze i doprinose u iznosu od oko jednog milijuna kuna koji bi se generirali do kraja mandata predstavljaju neefikasno trošenje proračunskih sredstava. 


\subsection{Diskusija}

Primjer grada Kastva se može argumentirati kao neprihvatljivo ustrojavanje izvršnog tijela jer se radi o gradonačelniku i njegovom zamjeniku koji se prema stupnju stručne spreme nalaze pri samom dnu u gradovima u Republici Hrvatskoj, tj. ostvarili su samo 39 glasova više u odnosu na protukandidate. Niskoobrazovani dužnosnici ne mogu obavljati složene poslove niti izvršavati funkcije javnih menadžera jer su njihove konceptualne i tehničke vještine insuficijentne. Oni nisu osposobljeni postaviti standarde performansi, mjeriti aktualne performanse i poduzimati korektivne mjere. Stoga bi zakonodavac morao propisati da takvi dužnosnici ne mogu obnašati funkcije općinskih načelnika, gradonačelnika i njihovih zamjenika profesionalno.

Rezultati istraživanja su pokazali da u gradu Kastvu nije potrebno da zamjenik gradonačelnika funkciju obnaša profesionalno jer petnaest gradova u Republici Hrvatskoj, koji su veći od grada Kastva, ima jednog dužnosnika koji funkciju obnaša profesionalno. Kako bi mogli ostvariti visoku razinu performansi, neophodno je da svi zaposleni temeljito poznaju svoj posao. Općinski načelnici, gradonačelnici i njihovi zamjenici također moraju razviti konceptualne i tehničke vještine koje su neophodne za obavljanje poslova menadžera najviše razine. U skladu s rezultatima istraživanja smatra se bitnim istaknuti kako bi hrvatski zakonodavac trebao propisati sljedeće u okviru zakonske regulative:

- ograničiti broj mandata općinskih načelnika, gradonačelnika i njihovih zamjenika na ukupno dva mandata kako bi se onemogućilo kontinuirano zapošljavanje nedostatno obrazovanih osoba kao javnih menadžera, ${ }^{19}$

- propisati izbor predsjednika predstavničkog tijela kako bi se izbjegli ekstremni slučajevi kad politička stranka koja ima jednog vijećnika ima i predsjednika.

Rezultati istraživanja su pokazali da službenici u lokalnoj samoupravi zaduženi za obavljanje funkcije javne nabave moraju biti raspoređeni $\mathrm{u}$ istu ustrojstvenu jedinicu kako bi kao javnonabavna služba kontinuirano mogli tražiti optimalnu kombinaciju ukupnih troškova i kvalitete koja zadovoljava zahtjeve građana. Isto tako rezultati istraživanja su pokazali kako organizacijsku strukturu u gradu Kastvu ne mogu projektirati gradonačelnik i njegov zamjenik čije je obrazovanje nisko i insuficijentno. U skladu s tim smatra se bitnim istaknuti kako bi hrvatski zakonodavac trebao propisati oblikovanje organizacijske strukture u manjim

19 Angažiranje jednog dužnosnika, čije su tehničke vještine i obrazovanje nedostatni, u vremenskom razdoblju od osam godina može generirati rashode za plaće i doprinose od dva milijuna kuna, a angažiranje dvaju takvih dužnosnika može generirati rashode za plaće i doprinose od četiri milijuna kuna. Javni menadžeri najviše razine moraju imati odgovarajuće konceptualne i tehničke vještine unatoč tome što se biraju političkim putem. 
gradovima i općinama te definirati upravna tijela i potrebna radna mjesta u korelaciji s njihovim fiskalnim kapacitetom, a s ciljem unapređenja upravljanja.

Prema odredbama Ustava Republike Hrvatske JLPRS imaju pravo u okviru zakona samostalno urediti unutarnje ustrojstvo i djelokrug svojih tijela. Isto tako prema Zakonu o potvrđivanju Europske povelje o lokalnoj samoupravi i ako to nije $\mathrm{u}$ suprotnosti s općim odredbama utvrđenim zakonom, lokalne jedinice mogu same određivati upravni ustroj kako bi ga prilagodile svojim potrebama i učinile upravljanje učinkovitijim. Međutim, niskoobrazovani dužnosnici nemaju odgovarajuće tehničke vještine za oblikovanje optimalne organizacijske strukture, prilagođene lokalnim potrebama, uz pomoć koje će se unaprijediti upravljanje i učiniti ga učinkovitijim. Niskoobrazovani dužnosnici su oblikovali nova radna mjesta. Povećanje ukupnog broja i nekompetentnih službenika u gradu Kastvu rezultira neučinkovitom i skupom lokalnom upravom. Politički menadžment ne smije vršiti selekciju nekompetentnih službenika po kriterijima političke vjernosti nego je potrebno provesti zakoniti postupak odabira putem natječaja i odabrati kandidate koji imaju najviše kvalifikacije iz određenog znanstvenog polja i znanstvene grane te odgovarajuće radno iskustvo. Hrvatski zakonodavac mora propisati da niskoobrazovani dužnosnici ne mogu obnašati funkcije profesionalno jer oni nemaju odgovarajuće konceptualne vještine i upravljačke kompetencije, pa se u takvim gradovima ne upravlja učinkovito i ostvaruju se niske razine performansi.

Rezultati istraživanja performansi lokalnog menadžmenta su pokazali kako razlika između cijene kupovine prostora za predškolski odgoj koju je ostvario grad Kastav i cijene gradnje, koju je mogao ostvariti da je objekt izgradio prema maksimalno ostvarenoj cijeni gradnje ili prema prosječnoj cijeni gradnje, iznosi četiri ili 5,6 milijuna kuna bez PDV-a. Ako dobivene rezultate usporedimo s rezultatima istraživanja Kontuš (2013), koji su pokazali kako javni menadžeri najviše razine u JLPRS moraju upotrebljavati ograničena proračunska sredstva odgovorno, učinkovito i efikasno u cilju ostvarivanja performansi koje poprimaju maksimalne vrijednosti, može se ustvrditi kako u gradu Kastvu proračunska sredstva nisu korištena učinkovito i efikasno.

U skladu s dobivenim rezultatima istraživanja, grad Kastav je za iznos od 10,7 milijuna kuna bez PDV-a mogao izgraditi objekt za predškolski odgoj za signifikantno više djece i dugoročno riješiti problem smještaja djece u objekte za predškolski odgoj ili izgraditi objekt za smještaj 100 djece, a ostvarenu razliku između cijene kupovine i cijene izgradnje objekta za smještaj 100 djece upotrijebiti za realizaciju drugih kapitalnih projekata. Ako dobivene rezultate usporedimo s rezultatima istraživanja Kontuš (2012), koji su pokazali kako bi zbog ograničenih proračunskih sredstava cilj javnih menadžera najviše razine trebao biti osiguranje aktivnog sudjelovanja privatnog sektora u financiranju i upravljanju projektima, 
može se ustvrditi kako su u gradu Kastvu primijenjeni ekstremni obrasci pri nabavi javnog objekta. Umjesto da se pokuša osigurati aktivno sudjelovanje istog privatnog investitora $u$ financiranju i upravljanju javnim objektom, ostvarena signifikantna razlika u cijeni pri kupovini javnog objekta od privatnog investitora sugerira kako je privatnom investitoru vjerojatno omogućeno ostvarivanje dobiti.

Poslove javnih menadžera najviše razine mogu obavljati kandidati koji su stekli potrebna specijalistička znanja te razvili konceptualne i tehničke vještine na poslijediplomskim studijima. Smatra se kako kandidati koji su niskoobrazovani mogu obavljati poslove niže složenosti, a ne složene poslove javnih menadžera najviše razine. ${ }^{20}$

Rezultati istraživanja sugeriraju kako se gradonačelnik i njegov zamjenik u gradu Kastvu moraju zamijeniti s povjerenikom Vlade jer su niskoobrazovani i nije potrebno da funkcije obnašaju profesionalno. Veći gradovi u Republici Hrvatskoj nemaju gradonačelnika ili zamjenika koji funkciju obnaša profesionalno (grad Ivanec). Isto tako, petnaest gradova koji su također veći od grada Kastva ima jednog dužnosnika koji funkciju obnaša profesionalno. Proračunska sredstva se ne smiju rasipati na prevelike kompenzacije gradonačelnika, općinskih načelnika i njihovih zamjenika koji su niskoobrazovani i/ili funkcije obnašaju profesionalno iako nije potrebno. U kontekstu svega izloženog, može se ustvrditi kako su rezultati istraživanja pokazali da bi grad Kastav trebao promptno dobiti povjerenika Vlade koji će zastupati interese građana te kako bi se ostvarila ušteda sredstva. Uza sve to, rezultati istraživanja upravljanja su pokazali sljedeće:

- Grad Kastav ne može imati javne menadžere najviše razine koji su sudjelovali u realizaciji nabave, tj. kupovine javnog objekta od privatnog investitora što je rezultiralo signifikantnom razlikom u cijeni u usporedbi s ostalim gradovima i općinama koji su objekte za predškolski odgoj izgradili.

- Grad Kastav ne može imati dva javna menadžera najviše razine koji su niskoobrazovani i nije potrebno da niskoobrazovani dužnosnici funkciju obnašaju profesionalno u gradu od posebnog povijesnog značenja, bogate prosvjetne tradicije i kulture, a ostvarili su samo 39 glasova više u odnosu na protukandidate.

- Nisko obrazovanje i insuficijentne tehničke vještine javnih menadžera najviše razine imaju negativne implikacije na izvršavanje osnovnih funkcija upravljanja (organiziranja, kadroviranja, vođenja i kontroliranja). Niskoobrazovani dužnosnici ne mogu izvršiti selekciju službenika i pročelnika te oblikovati organizacijsku strukturu u korelaciji sa svojim interesima jer je to

20 Npr., dužnosnicima će kognitivne sposobnosti koje su ih onemogućile u završetku preddiplomskog studija predstavljati prepreku u obavljanju poslova općinskih načelnika i gradonačelnika jer su njihovi su ishodi učenja bili ne zadovoljava. 
u suprotnosti s općim odredbama zakona i odredbama Zakona o potvrđivanju Europske povelje o lokalnoj samoupravi.

- Rashodi za kompenzacije javnih menadžera najviše razine nisu u korelaciji s ostvarenim niskim razinama performansi te performansi koje nisu pozitivne. ${ }^{21}$

Naposljetku, smatra se potrebnim predložiti mjere za unapređenje sustava upravljanja u gradu Kastvu:

- Gradonačelnik i njegov zamjenik u gradu Kastvu se moraju zamijeniti s povjerenikom Vlade jer su niskoobrazovani i nije potrebno da funkcije obnašaju profesionalno.

- Povjerenik Vlade mora imenovati pročelnike upravnih odjela koji imaju razvijene tehničke vještine i potrebna znanja iz područja rada upravnog odjela i upravljanja poslovnim sustavima te koji mogu samostalno rješavati probleme iz područja rada upravnog odjela.

- U gradu Kastvu je potrebno oblikovati organizacijsku strukturu po načelima znanstvenog upravljanja jedinicama lokalne samouprave kako bi se nestručni službenici sa završenim neodgovarajućim i najnižim studijem zamijenili sa službenicima koji imaju razvijene tehničke vještine i potrebna znanja iz odgovarajućeg znanstvenog polja i znanstvene grane te odgovarajuća iskustvena znanja. Esencijalna ideja oblikovanja ovakve organizacije je rješavanje problema i postizanje efikasnosti.

- Nakon projektiranja optimalne organizacijske strukture sa stvarno potrebnim radnim mjestima povjerenik Vlade ili javni menadžeri, koji imaju potrebne tehničke vještine, bi trebali izraditi analizu kompetencija službenika. U skladu s dobivenim rezultatima u gradu Kastvu je potrebno raspisati natječaje za radna mjesta na kojima su dužnosnici s niskim ili neodgovarajućim kvalifikacijama zaposlili nestručne službenike kako bi se putem natječaja odabrali

${ }^{21}$ Ostvarene performanse koje nisu pozitivne su prethodno elaborirane, a uključuju sljedeće: sudjelovanje u kupovini javnog objekta od privatnog investitora umjesto njegove izgradnje, nepravodobnu izgradnju groblja, pogrešno oblikovana ili bespotrebna radna mjesta, nepravilno izvršavanje funkcija upravljanja (organiziranja, kadroviranja) i sl. Kupovina javnog objekta od privatnog investitora ne predstavlja nabavu javnog objekta na racionalan način jer se javni objekti grade kako bi se ostvarila najniža cijena i najviša kvaliteta. Izdavanje zastarjelih novina u digitalnoj eri također predstavlja neefikasno korištenje proračunskih sredstava. Urednik novina je povezan s predsjednikom suda gdje su se vodili sporovi protiv gradonačelnika, a povezanost je potvrđena pri rješavanju zahtjeva za izuzećem sudaca. Ovo se može determinirati kao pojava koja je za istraživača neshvatljiva i koja proturiječi očekivanjima te predstavlja izazovno područje za provođenje istraživanja. Potrebno je naglasiti kako su proslave Adventa i ostale proslave uz ponudu hrane i zabave u korelaciji s primitivnim okruženjem kakvom ne pripada grad Kastav koji ima bogatu prosvjetnu tradiciju i kulturu. 
kandidati koji imaju najviše kvalifikacije iz određenog znanstvenog polja i znanstvenih grana te odgovarajuće radno iskustvo.

Niskoobrazovani dužnosnici mogu ostvariti pravo da budu birani, ali bi u takvu slučaju trebali odabrati alternativnu mogućnost da funkciju neće obnašati profesionalno, te bi ostvarivali pravo na odgovarajuću naknadu iz proračuna. Dužnosnici koji su niskoobrazovani i funkciju obnašaju profesionalno bi morali obrazložiti građanima što će raditi profesionalno tj. savjesno, vješto i temeljito, odnosno čime će ostvarivati prava na kompenzacije iz proračuna. Niskoobrazovani gradonačelnici ne mogu identificirati rezultate rada pročelnika, interpretirati i vrednovati njihove rezultate rada, odnosno ocjenjivati pročelnike.

Ograničena proračunska sredstva se moraju upotrebljavati odgovorno, učinkovito i efikasno u cilju ostvarivanja performansi koje poprimaju maksimalne vrijednosti te se ne mogu rasipati na kompenzacije općinskih načelnika, gradonačelnika i njihovih zamjenika koji su niskoobrazovani i funkcije obnašaju profesionalno iako nije potrebno. Niskoobrazovani dužnosnici i nestručni službenici koji nemaju odgovarajuća znanja i tehničke vještine mogu ostvariti niže razine performansi, a visokoobrazovani službenici u takvim okolnostima nemaju s kime surađivati u cilju ostvarivanja performansi koje poprimaju maksimalne vrijednosti.

Uza sve to rezultati istraživanja su pokazali da tri grada u Republici Hrvatskoj imaju samo jednog dužnosnika koji funkciju obnaša profesionalno i koji ima srednju stručnu spremu što dokazuje da je politički menadžment u gradovima irelevantan, te da treba ograničiti broj dužnosnika koji funkciju obnašaju profesionalno. Isto tako potrebno je odabrati kompetentne službenike koji imaju odgovarajuća znanja i tehničke vještine iz odgovarajućeg znanstvenog polja i znanstvene grane te odgovarajuće radno iskustvo. Uspješnost jedinica lokalne samouprave izražena ekonomskim performansama povezana je s upravljačkim kompetencijama političkog menadžmenta. Rezultati istraživanja učinkovitosti upravljanja omogućuju objektivno sagledavanje uloge lokalnog političkog menadžmenta u kreiranju razvojnih politika koje se odražavaju na prosperitet jedinice lokalne samouprave. ${ }^{22}$ Korelacija između učinkovitosti upravljanja lokalnog političkog menadžmenta i stupnja gospodarskog razvoja ima utjecaja na razvoj svijesti o prednostima izbora kompetentnih u odnosu na politički etablirane lokalne menadžere.

U kontekstu svega izloženog može se ustvrditi da gradonačelnici i općinski načelnici koji funkciju obnašaju profesionalno moraju imati odgovarajuće

22 Npr., poduzetnička zona u gradu Kastvu se razvijala do 2004. godine, a nakon toga stagnira. Srednje veliko proizvodno poduzeće je napustilo poduzetničku zonu zbog ostvarivanja boljih uvjeta za poslovanje i rast u poduzetničkoj zoni koja se kontinuirano razvija. 
konceptualne i tehničke vještine kako bi razumjeli ovlasti gradonačelnika i općinskih načelnika, te s mnogo znanja i umijeća upravljali gradovima i općinama. Njihov utjecaj na kreiranje strateških ciljeva i motivaciju suradnika u dosezanju ciljeva je presudan za postizanje izvrsnosti i kontinuiranog napretka. Zaključno se može ustvrditi da bi grad Kastav trebao imati jednog dužnosnika koji funkciju obnaša profesionalno i koji ima odgovarajuće strategijske vještine i upravljačke kompetencije jer je on odgovoran za strateško usmjeravanje grada i postizanje kontinuiranog napretka. Uza sve to, smatra se potrebnim istaknuti kako različiti oblici ekstremnih pojava imaju negativne implikacije na civilizacijska dostignuća grada te predstavljaju aktualni problem istraživanja. Sukladno tome, potrebno je provesti istraživanje kako bi se identificirali uzroci ekstremnih pojava te riješio problem ekstremnih pojava u sustavu lokalne samouprave.

\section{ZAKLJUČAK}

U ovom se radu analiziraju instrumenti za postavljanje dobre strategije upravljanja u sustavu lokalne samouprave, zakonski okvir kojim se regulira upravljanje u sustavu lokalne samouprave te se daju prijedlozi za izmjene zakona radi unapređenja upravljanja. Problemi agenata, koji se pojavljuju kad određene interesne skupine vode poslove za druge interesne skupine te ako jedna interesna skupina forsira svoje interese na račun druge interesne skupine, predstavljaju ozbiljnu prijetnju uspješnom upravljanju u sustavu lokalne samouprave. Naposljetku smatra se bitnim istaknuti kako bi hrvatski zakonodavac trebao propisati sljedeće:

Zakonodavac bi trebao propisati broj dužnosnika koji funkciju mogu obnašati profesionalno u korelaciji s fiskalnim kapacitetom i brojem stanovnika u JLS.

Zakonodavac bi morao propisati mehanizme da gradonačelnici i općinski načelnici budu promptno zamjenjivi raspisivanjem novih izbora u slučaju njihove povezanosti s koruptivnim aktivnostima i kad razina njihovih konceptualnih i tehničkih vještina ima negativne implikacije na ostvarivanje performansi kao i u slučaju zlouporabe ovlasti gradonačelnika i općinskih načelnika.

Zakonodavac bi morao propisati određivanje plaća gradonačelnika, općinskih načelnika i zamjenika u skladu s fiskalnim kapacitetom gradova i općina, ali i prema stupnju njihove stručne spreme.

Zakonodavac bi morao izmijeniti uvjet da za općinskog načelnika, gradonačelnika, župana i njihove zamjenike imaju pravo biti birani svi birači koji na dan stupanja na snagu odluke o raspisivanju izbora imaju najmanje šest mjeseci prijavljeno prebivalište na području JLPRS te propisati određene uvjete odnosno da kandidati moraju imati odgovarajuća znanja i vještine koja se stječu u procesu 
obrazovanja. Smatra se potrebnim propisati testiranje inteligencije kandidata za općinske načelnike, gradonačelnike i njihove zamjenike kako ne bi kandidati s niskom ili ispod prosječnom inteligencijom, odnosno oni koji ne razumiju ovlasti općinskih načelnika i gradonačelnika, imali takve ovlasti.

Rezultati empirijskog istraživanja provedenog u ovom radu i analize slučaja potvrđuju postavljenu hipotezu istraživanja: Hrvatski zakonodavac bi morao izmijeniti postojeću pravnu regulativu kojom se uređuje izbor općinskih načelnika, gradonačelnika i njihovih zamjenika te sustav upravljanja u JLPRS s ciljem unapređenja sustava upravljanja i bolje primjene prava u JLPRS. Analiza problema agenata predstavlja ograničenje ovog istraživanja, ali i izazovno područje za provođenje budućih istraživanja.

\section{LITERATURA}

1. Aras, S., (2007), Korupcija, Pravnik, vol. 41, no. 84, str. 25-59. .

2. Bateman, S. T., Zeithaml, P. C. (1993), Management: Function and Strategy, Bur Bridge, Illionis

3. Bogović, T. (2014) Ocjena učinkovitosti upravljanja hrvatskim gradovima metodom omeđivanja podataka, Fakultet organizacije i informatike, Varaždin

4. Buble, M., (2006), Menadžment, Sveučilište u Splitu, Ekonomski fakultet, Split

5. Budak, J., (2006) Corruption in Croatia: Perceptions Rise, Problem Remains, Croatian Economic Survey, vol. 9, no. 1, str. 35-68.

6. Budak, J., (2016) Korupcija u javnoj nabavi: trebamo li novi model istraživanja za Hrvatsku? Ekonomski pregled, vol. 67, no. 4, str. 306-327.

7. Budimirović, M. (2017) Izazovi upravljanja lokalnom samoupravom, Škola biznisa, 1.

8. Dujanić, M., (2006), Projektiranje organizacije i upravljanje projektima, Veleučilište u Rijeci, Rijeka

9. Derenčinović, D., (2001). Mit o korupciji, NOCCI, Zagreb

10. Grubiša, D., (2010), Anti-corruption Policy in Croatia: Benchmark for EU Acesion, Politička misao, vol. 47, no. 5, str. 69 - 95.

11. Jensen, M., Meckling, W., (1976), Theory of the Firm: Managerial Behavior, Agency costs and Ownership structure, Journal of Financial Economics, vol. 3, str. 305-360.

12. Kontuš, E., (2012), Financing of Public Investments: A Case of an Enterprise Zone, International Journal of Sales, Retailing and Marketing, vol. 11, no. 3, str. 122. 
13. Kontuš, E., (2013), Managing Cash and Liquidity of the Budget: a case of regional and local budget, International Journal of Management Cases, vol. 15 , no. 4 , str. 341.

14. Koontz, H., Weihrich, H. (1988), Management, Mcgraw-Hill Company, New York

15. Koprić, I. (2018) Suvremeni trendovi u razvoju lokalne samouprave, Institut za javnu upravu, Zagreb

16. Kregar, J., (1997), Protiv korupcije, Državnost, vol. 1, no. 3, str. 414 - 415.

17. Kreitner, R., (1989), Management, Houghton Mifflin Company, Boston

18. Lamza-Marović, M., Glavaš, J., Bošnjak, S. (2008) Contribution to the Development of the Urban Management Model, Interdisciplinary Management Research, vol. IV, Faculty of Economics, Osijek

19. Lozina, D., Jerkić, I. (2018) Refleksije o lokalnoj hrvatskoj samoupravi, Zbornik radova Pravnog fakulteta u Splitu, vol. 55, no. 3, str. 683-695.

20. Reddin, W., (1970), Managerial Effectiveness, Mcgraw-Hill Book Company, New York

21. Sljepčević, S., Rajh, E., Budak, J. (2018) Analiza izloženosti korupcijskim pritiscima na lokalnoj razini vlasti u Europi, Ekonomski pregled, vol. 69, no. 4, str. 329-349.

22. Zakon o sustavu unutarnjih kontrola u javnom sektoru, Narodne novine, br. $78 / 15$

23. Zakon o proračunu, Narodne novine, br. 87/08, 136/12, 15/15

24. Zakon o službenicima i namještenicima u lokalnoj i područnoj (regionalnoj) samoupravi, Narodne novine, br. 86/08

25. Zakon o lokalnim izborima, Narodne novine, br. 144/12, 121/16

26. Zakon o potvrđivanju Europske povelje o lokalnoj samoupravi, Narodne novine, Međunarodni ugovori, br. 14/97, 04/08

27. Izvještaj o izvršenju proračuna Grada Kastva za 2017. godinu, Službene novine Primorsko-goranske županije, br. 21/18

28. Službene stranice grada Kastva, http://www.kastav.hr/ pristupljeno 02 prosinca 2018.

29. Službene stranice grada Novske, http://novska.hr/ pristupljeno 02 prosinca 2018.

30. Službene stranice grada Osijeka, http://www.osijek.hr/ pristupljeno 02 prosinca 2018.

31. Službene stranice grada Požege, http://www.pozega.hr/ pristupljeno 02 prosinca 2018. 
32. Službene stranice grada Slavonski Brod, http://www.slavonski-brod.hr/ pristupljeno 02 prosinca 2018.

33. Službene stranice općine Gornji Kneginec, https://www.kneginec.hr/ pristupljeno 02 prosinca 2018.

34. Službene stranice općine Jakšić, http://www.jaksic.hr/ pristupljeno 02 prosinca 2018.

35. Službene stranice Općine Križ, http://www.opcina-kriz.hr/ pristupljeno 02 prosinca 2018.

36. Službene stranice općine Sveta Nedelja, http://www.sv-nedelja.hr/ pristupljeno 02 prosinca 2018.

37. Registar dužnosnika, http://www.sukobinteresa.hr/hr/registar-duznosnika/. pristupljeno 05 prosinca 2018. 
Elenora Kontuš, PhD

Rijeka, Croatia

eleonora.kontus@ri.t-com.hr

\title{
MANAGEMENT SPECIFICITIES AND DEVIATIONS IN THE LOCAL SECTOR - CITY OF KASTAV: CASE ANALYSIS
}

Received: July 16, 2019

Accepted: September 16, 2019

Professional paper

\begin{abstract}
The paper discusses the management system and deviations that occur in the local sector. The objectives of this research are to investigate the performance of top-level public managers and to explore the legal framework governing the management system as well as the irregularities in its application. In the empirical part of the study the performance of top-level public managers in the local sector are analysed and the results are compared in order to identify the performance common characteristics as well as differences between the performance of top-level public managers. The results of the research point to the possible agency problems in cases when certain interest groups conduct business for other interest groups and when one particular interest group or some public managers force their interests to the detriment of citizens. The paper points to the irregularities in the interpretation and application of the existing legal text and stresses the need to modify the existing legislation in order to enable better enforcement of rights and improve the system of management in the local sector.
\end{abstract}

Keywords: management, local sector, public managers, legislation, agency problems;

JEL: H0 